\title{
Analgesic Appraisal of Bidens pilosa (Asteraceae) Leaf Extracts Used in Management of Oral Lesion Pain in HIV/AIDS Patients in Rodents
}

\author{
Joseph Obiezu Chukwujekwu Ezeonwumelu1,2,3,4*, Muhammad Ntale5, \\ Steve Okwudili Ogbonnia6, Ezera Agwu7,8, Julius Kihdze Tanayen ${ }^{3,9}$, \\ Ahmed Adebowale Adedeji10,11, Chukwudi Onyeka Okonkwo ${ }^{3,12}$, \\ Ambrose Amamchukwu Akunne,,13, Jennifer Chibuogwu Ebosie ${ }^{4,13}$, Frederick Byarugaba14
}

${ }^{1}$ Department of Pharmacy, Faculty of Medicine, Mbarara University of Science and Technology, Mbarara, Uganda ${ }^{2}$ Department of Clinical and Biopharmacy, School of Pharmacy, Kampala International University Western Campus, Ishaka, Uganda

${ }^{3}$ Kampala International University Complementary and Alternative Medicine Research (KIUCAMRES) Group, Ishaka, Uganda ${ }^{4}$ Department of Public Health, Faculty of Applied Sciences, Bishop Stuart University, Mbarara, Uganda

${ }^{5}$ Department of Chemistry, Makerere University, Kampala, Uganda

${ }^{6}$ Department of Pharmacognosy, Faculty of Pharmacy, Chukwuemeka Odumegwu Ojukwu University, Uli, Anambra State, Nigeria ${ }^{7}$ Department of Microbiology, Faculty of Biomedical Sciences, Kampala International University Western Campus, Ishaka, Uganda ${ }^{8}$ Department of Medical Microbiology and Immunology, University of Kabale, Kabale, Uganda

${ }^{9}$ Department of Pharmacology and Therapeutics, Faculty of Medicine, Mbarara University of Science and Technology, Mbarara, Uganda

${ }^{10}$ Department of Pharmacology and Toxicology, School of Pharmacy, Kampala International University Western Campus, Ishaka, Uganda

${ }^{11}$ Department of Pharmacology, University of Gitwe, Gitwe, Rwanda

${ }^{12}$ Department of Human Physiology, Faculty of Basic Medical Sciences, College of Medicine, Nnewi Campus, Nnamdi Azikiwe University, Nnewi, Nigeria

${ }^{13}$ Department of Clinical and Biopharmacy, School of Pharmacy, Kampala International University Western Campus, Ishaka, Uganda ${ }^{14}$ Department of Microbiology, Faculty of Medicine, Mbarara University of Science and Technology, Mbarara, Uganda

Email: *nduezeh@gmail.com

How to cite this paper: Ezeonwumelu, J.O.C., Ntale, M., Ogbonnia, S.O., Agwu, E., Tanayen, J.K., Adedeji, A.A., Okonkwo, C.O., Akunne, A.A., Ebosie, J.C. and Byarugaba, F. (2018) Analgesic Appraisal of Bidens pilosa (Asteraceae) Leaf Extracts Used in Management of Oral Lesion Pain in HIV/AIDS Patients in Rodents. Pharmacology \& Pharmacy, 9, 175-192. https://doi.org/10.4236/pp.2018.96014

Received: January 16, 2018

Accepted: June 26, 2018

Published: June 29, 2018

\begin{abstract}
Oral lesions, diarrhoea, Pneumocystis carinii pneumonia, tuberculosis and urinary tract infections are some of the opportunistic infections (OIs) which arise when the CD4 cells of the HIV/AIDS patient fall below 200 cells $/ \mathrm{mm}^{3}$. HIV/AIDS infection complications include tissue damage from oral lesions accompanied with pains. Pain is a disagreeable sensory and sensitive experience associated with actual or potential tissue damage. This condition requires immediate treatment with analgesics and antibiotics. However, the inability of rural dwellers to afford readily available drugs is a consequence for
\end{abstract}


Copyright (c) 2018 by authors and Scientific Research Publishing Inc. This work is licensed under the Creative Commons Attribution-NonCommercial International License (CC BY-NC 4.0). http://creativecommons.org/licenses/by-nc/4.0/ (c) (i) (8) Open Access using herbs like Bidens pilosa whose local usefulness in the management of oral lesions of HIV/AIDS has not been proven scientifically. Therefore, the objective of this study was to provide the scientific basis in rats for the traditional healers' use of Bidens pilosa leaves' extracts in managing pain associated with oral lesions of HIV/AIDS patients in South Western Uganda. Assessment of the analgesic effects of Bidens pilosa was conducted using acetic acid in mice, formalin-induced pain and tail flick methods in rats. Both aqueous and ethanolic extracts of the leaves of Bidens pilosa produced statistically significant dose dependent inhibition of acetic acid induced pain, non dose dependent pain reduction in formalin induced pain, $(\mathrm{p}<0.05$; student $\mathrm{t}$-test) and non dose dependent tail withdrawal pattern $(\mathrm{p}<0.05$, Multivariate ANOVA test). Hence, we conclude that extracts of Bidens pilosa have an analgesic basis for their local use in treatment of oral lesions associated pain in HIV/AIDS patients in South-Western Uganda.

\section{Keywords}

Local Use, Bidens pilosa, Pain, Oral Lesion, HIV/AIDS, Rodents

\section{Introduction}

Pain is an unpleasant sensory and emotional experience associated with actual or potential tissue damage [1]. The word "unpleasant" describes various levels of inconvenience, misery, anguish, anxiety, depression, desperation and ultimate remedy of suicide [2] [3]. In Africa, many researchers such as [4] [5] [6] [7] [8] have all reported high prevalence of oral lesions associated with HIV/AIDS, with oral candidiasis being very prevalent (50\% - 80\%). In Uganda, two studies [9] [10] reported a high prevalence $(70 \%-80 \%)$ of oral candidiasis and oral bacterial infections among HIV/AIDS patients. Some forms of oral lesion or oral tissue damage occur and may include major aphthous ulceration (most common, 2\% 3\%) [11]; necrotizing stomatitis (painful ulceration which exposes underlying bone and leads to tissue destruction) and recurrent aphthous ulcerations (present on non-keratinized tissues such as labial and buccal mucosa, the floor of the mouth, ventral surface of the tongue, posterior oropharynx and the maxillary and mandibular vestibules). Pain increases upon eating salty, spicy, acidic foods or beverages and due to trauma when consuming hard or rough foods [12]. The pain as discomforting as it may be, requires immediate treatment with analgesic agents and antibiotics. But some of the available drugs are either not affordable, not accessible or socially and culturally not acceptable to the rural populace and for some who can afford to buy the drugs, adverse effects of the drugs e.g. gastric irritation of non steroidal anti-inflammatory drugs may not allow them to use the drugs as required [13] [14]. This makes room for them to resort to use of herbs. Anecdotal evidence from South Africa suggests that a number of antiretroviral therapy (ART) patients resort to traditional medicine after experiencing side effects from ART. Studies have found that HIV positive 
persons use traditional and alternative medicines at high rates between $15 \%$ and 79\%, higher than people with other serious illnesses [15] [16] [17]. A study on the use of traditional herbal medicine was conducted on 137 AIDS patients in Kabarole District, Western Uganda, for relief of pain and fever [18]. One of the most highly used herbs by traditional healers and local people in South Western Uganda in treating the pain associated with oral lesions of HIV/AIDS patients is Bidens pilosa (Unpublished data). The traditional healers and local users of $B i$ dens pilosa in South-Western Uganda were ascertained to prepare decoctions of the leaves of the herb with water and by soaking in ethanol for some days. This observation forms the basis for our use of water and ethanol in the extraction of Biden pilosa leaves for this study (Unpublished data). Bidens pilosa, an Asteraceae, is a cosmopolitan, annual herb which originates from the tropics especially Central America, Africa and Asia [19]. B. pilosa is an erect, tall branched, perennial plant with green leaves, thin white or yellow flowers that develop into a cluster of tiny, barbed black seeds with short, stiff hairs which stick to feathers, fur, or socks and other such materials [3] [10] [11] [20] [21] [22] [23]. It has many common names which include black-jack, [4] [24] beggar-ticks, cobbler's pegs, farmer's friends [5] [25] and Spanish needle [2] [6] [7] [8] [9] [26] [27] [28] [29] [30]. It is called "Enyabarashana" in Runyankole language in Uganda and "Ogwumma" in Igbo language in Nigeria. It is globally distributed and widely used as a folk remedy, serving as an extraordinary source of food and medicine [20]. Bidens pilosa serves as a medicinal plant in areas of Africa, Asia, and tropical America. Its different parts e.g. roots, leaves, and seeds are informed to be used against bacteria, dysentery, inflammation, microbes, and malaria; for diuretic, hepatoprotection, and hypotension. In Africa and tropical areas of Central and Southern America, tropical and subtropical areas of Asia, B. pilosa is reported in folk medicine for treatment of headaches, ear infections, hangovers, diarrhoea, kidney problems, malaria, jaundice, dysentery, burns, arthritis, inflammatory disorders, ulcers, abdominal symptoms and facilitation of child labour; and studies have demonstrated its anaesthetic, antibacterial, antidiabetic andcoagulant activities [31]-[36]. It is also used in Uganda by traditional healers in the treatment of opportunistic infections of HIV/AIDS patients mostly oral lesions as reported by the local people (Unpublished data). B. pilosa is claimed to treat more than 40 disorders, and 201 compounds have been identified from this plant. Polyynes, flavonoids, phenylpropanoids, fatty acids, and phenolics are the primary bioactive compounds of $B$. pilosa, and they have been reported by some studies to be effective in the treatment of tumours, inflammation/immune modulation, oxidative processes, diabetes and hyperglycaemia, viruses, bacteria, fungi, protozoans and other microbes, wounds, gastrointestinal diseases, hypertension, vasoconstriction, ulcer, and cardiovascular diseases. However, caution should be exercised in the therapeutic use of B. pilosa for hypoglycaemia, hypotension, bleeding, and allergy [20]. Generally, there is need for evidence-based research on herbal medicines when quality, efficacy, safety and well-defined cause/effect relationships are on discourse [37]. In this study, we investigated the 
scientific basis for ethnomedical use of extracts of Bidens pilosa leaves in the management of the pain involvement of oral lesions of HIV/AIDS patients in South Western Uganda.

\section{Materials and Methods}

\subsection{Plant Extract}

Extracts were obtained from the air-dried, ground Bidens pilosa leaves using a 1-hour hot water extraction method for aqueous extracts and a 72-hour cold ethanolic extraction method according to the procedure used by traditional and local users of the herb. It was ascertained that the local people usually boil the plant materials in water for their extraction either as decoction or infusion and few others soak plant materials in cold alcohol locally called waragi. Thus, extracts were obtained using these methods. For an aqueous extract, $200 \mathrm{~g}$ of plant material was soaked and boiled in $1000 \mathrm{~mL}$ of clean distilled water in a clean beaker for one hour. The extraction in cold ethanol was carried out with $200 \mathrm{~g}$ of plant material soaked in $1000 \mathrm{~mL}$ of absolute ethanol for 72 hours with occasional shaking using the electronic shaker ( $\mathrm{Nüve}^{\circledast}$ SL 350, serial number: 02-0974, Ankara, Turkey). Thereafter, the boiled and cold soaked plant materials were each filtered using clean white cotton cloth and subsequently using No.1 Wattmann's filter papers to obtain particle free filtrate. The filtrate for the aqueous extract was dried by boiling off all water elements in a water bath at $100^{\circ} \mathrm{C}$ while filtrate for the ethanolic extract was dried by evaporation in a hot air oven at $40^{\circ} \mathrm{C}$. The extracts were stored without solvent at freezing temperature $\left(-20^{\circ} \mathrm{C}\right)$ with minimal exposure to freeze-thaw cycles and humidity [38]. Freshly prepared solution of aqueous extracts was always reconstituted in distilled water and suspensions of ethanolic extract was always reconstituted with little amount of Tween 80 in distilled water ready for use in the studies.

\subsection{Animals}

Swiss albino mice were used for acetic acid induced pain tests while Wistar rats were used for formalin and tail-flick induced pain tests. These animals were obtained from the Animal Facility Centre (AFC) of Kampala International University, Western Campus, Ishaka. The animals were kept in a cage lined with wood shavings, at room temperature with adequate ventilation, under a naturally illuminated environment with $12 \mathrm{~h}$ of light and $12 \mathrm{~h}$ of darkness. They were fed with standard diet (Nuvita ${ }^{\circledR}$ Animal Feeds Ltd., Jinja Uganda). They were allowed access to clean drinking water ad libitum. The animal experiments were carried out according to the National Institute of Health Guide for the care and use of laboratory animals [39] and ethical guidelines for investigation of experimental pain in animals [40].

\subsection{Acetic Acid-Induced Writhing Test (Chemical)}

Each rat was placed inside a transparent observation cage $(40 \times 30 \times 20 \mathrm{~cm})$ for 
an acclimatization period of $30 \mathrm{~min}$. This test was carried out with the methods described by Koster et al. [41] and Collier [42], with slight modification. The modification applied was that one set of experiments was conducted $30 \mathrm{~min}$ after pretreatment with the negative, positive standard and test drugs. One set of five groups of mice $(\mathrm{n}=5)$ were pretreated with each of the aqueous and ethanolic Bidens pilosa extracts (200, 400 and $800 \mathrm{mg} / \mathrm{kg})$, distilled water $(10 \mathrm{~mL} / \mathrm{kg})$ and aspirin $(150 \mathrm{mg} / \mathrm{kg})$. Each mouse was injected with $0.7 \%$ of an aqueous solution of acetic acid (10 $\mathrm{mL} / \mathrm{kg}$, i.p) after the predetermined time (30 min) and placed in transparent observation cage. The number of writhes (abdominal musculature constriction followed by extension of the hind limbs [43] exhibited by each mouse was cumulatively counted for 15 minutes after 5 minutes lag time of the aqueous acid injection [44] and the mean count of each group taken.

\subsection{Formalin Test (Chemical)}

This test was carried out in five groups of rats $(n=5)$ pretreated with either distilled water $(10 \mathrm{~mL} / \mathrm{kg})$; the aqueous extract, ethanolic extract $(200,400$ and 800 $\mathrm{mg} / \mathrm{kg}$ p.o.) or acetylsalicylic acid (aspirin) (100 mg/kg) using the Dubuisson and Dennis method [45] modified by Tjolsen [46]. Formaldehyde $(0.05 \mathrm{ml}$, 2.5\%) was injected into the sub-plantar surface of the rat left hind paw $30 \mathrm{mi}$ nutes after the treatment. Severity of pain was rated in two distinct phases for 1 hour; in first phase ( 0 - 10 minutes), readings were taken every 2 minutes and in late phase (15 - 60) minutes, readings were taken every 5 minutes using Dubuisson and Dennis method [45] of pain scoring measurements in the following manner: $(0)=$ normal weight bearing on the injected paw; $(1)=$ light resting of the paw on the floor; (2) = elevation of the injected paw; and (3) = licking, biting and grooming of paw. These responses were observed and recorded for a total of 60 minutes. The first 10 minutes was considered as the early phase representing aphasic (Central Nervous System) pain while the period between 15 and 60 minutes was recorded as the late phase representing tonic (peripheral/inflammatory) pain. The mean \pm SEM of the readings was recorded as the pain score.

\subsection{Tail-Flick Test (Thermal)}

Tail-flick test or thermal test was conducted with method of D'Armour and Smith [47], as subsequently modified for rats using hot water bath [48] [49] [50] [51] [52] with minor modifications for our local laboratory settings. The rats were initially screened for the test by immersing about $2 \mathrm{~cm}$ of their tails (initially measured and marked out with a marker pen from the tip of the rats' tail) into hot water maintained at $55^{\circ} \mathrm{C} \pm 1^{\circ} \mathrm{C}$ in a water bath. The animals that lifted their tails out of water within 5 seconds were selected for the study. A cut-off time was set at 6 seconds to prevent the rats' tail from damage by hot water. Thirty rats that showed response (withdrawing the tail within 5 seconds) were selected and grouped into 6 groups of $5(n=5)$. The rats in the six groups were 
treated with the aqueous and ethanolic Bidens pilosa extracts (200, 400 and 800 $\mathrm{mg} / \mathrm{kg}$ ), morphine ( $2 \mathrm{~mL} / \mathrm{kg}$, i.p) as positive control for morphine-like activity of Bidens pilosa extracts and aspirin (100 mg/kg p.o) as positive control for NSAID-like activity of Bidens pilosa extracts and distilled water $(10 \mathrm{~mL} / \mathrm{kg})$ as negative control. The tail withdrawal reflex period (latency/pain threshold) was taken at 30 and 60 minutes after treatment and recorded.

\subsection{Statistical Analysis}

Data were entered into the Excel sheet and means were calculated. Student t-test, test of between-subject effects applying multivariable Analysis Of Variance (ANOVA) and multiple comparison tests applying Tuskey HSD, Scheffe, LSD or Dunnett $t$ 2-paired tests were used to compare the means to obtain the $\mathrm{p}$ values from treated and control groups of rats with the help of Statistical Package for Social Sciences (SPSS 20.0) soft wares. Results were expressed as mean \pm SEM. Statistical significance was taken as $\mathrm{p}<0.05$ and confidence interval at $95 \%$.

\section{Results}

\subsection{Results of Tests of Bidens pilosa Extracts on Acetic Acid-Induced Writhing in Mice}

In Table 1, for both aqueous and ethanolic extracts of Bidens pilosa, the acetic acid induced writhes in the mice were inhibited dose-dependently and significantly ( $\mathrm{p}<0.05$; student $\mathrm{t}$-test) in the same manner as acetylsalicylic acid. Therefore, the activities exhibited by both extracts were comparable to that of positive control (acetylsalicylic acid) though it could be seen from the results that the activity displayed by the aqueous extract was better than the activity of the ethanolic extract at the three different dose levels. Multiple dose analysis with Analysis Of Variance (ANOVA) of acetic acid induced pain inhibition indicated statistically significant relationship $(\mathrm{p}<0.05)$ between $200 \mathrm{mg} / \mathrm{kg}$ dose $(\mathrm{p}$ $=0.01)$ and $400 \mathrm{mg} / \mathrm{kg}$ dose $(\mathrm{p}=0.001)$ of the extracts of Bidens pilosa (test of between-subjects effects). When the effects of the various doses of aqueous extract

Table 1. Acetic acid-induced writhing test of aqueous and ethanolic extracts of Bidens pilosa in rats.

\begin{tabular}{|c|c|c|c|c|c|c|c|c|}
\hline \multirow{3}{*}{ Dose (mg/kg) } & & \multicolumn{7}{|c|}{ Treatments } \\
\hline & Normal saline & ASA & & $\mathrm{BPA}$ & & & $\mathrm{BPE}$ & \\
\hline & $10 \mathrm{~mL} / \mathrm{kg}$ & 150 & 200 & 400 & 800 & 200 & 400 & 800 \\
\hline $\begin{array}{l}\text { Mean writhes } \\
\text { count } \pm \text { SEM } 30 \text { mins } \\
\text { after pretreatment }\end{array}$ & $36.20 \pm 5.02$ & $0.60 \pm 0.60^{*}$ & $1.60 \pm 0.51^{\star}$ & $0.60 \pm 0.40^{*}$ & $0.20 \pm 0.20^{*}$ & $2.20 \pm 0.86^{*}$ & $1.20 \pm 0.80^{*}$ & $0.60 \pm 0.60^{*}$ \\
\hline $\begin{array}{c}\text { \% Inhibition } \\
\text { of pain } \\
\text { (Antinociceptive effect) }\end{array}$ & - & 98.3 & 95.6 & 98.3 & 99.5 & 93.6 & 96.5 & 98.3 \\
\hline
\end{tabular}

$\mathrm{n}=5$; Data were mean $\pm \mathrm{SEM}$; ${ }^{\star}=$ test groups varied significantly $(\mathrm{p}<0.05)$ from normal saline group using student $\mathrm{t}$-test; ASA = Acetylsalicylic acid; BPA = Bidens pilosa leaf Aqueous extract; $\mathrm{BPE}=$ Bidens pilosa leaf Ethanolic extract. 
of Bidens pilosa were compared with those of the ethanolic extracts using Dunnett $t$ 2-paired multiple comparisons tests, it showed that there was no significant difference ( $p=1.00$ and $>0.05)$ in analgesic activity between the aqueous and ethanolic extracts.

\subsection{Results of Tests of Bidens pilosa Extracts on Formalin-Induced Pain in Rats}

Table 2 displays the results of the effects of acute administration of Bidens pilosa on formalin induced pain in rats. The general trend of pain reduction activity in both phases of formalin induced pain for aqueous and ethanolic extracts of $B i$ dens pilosa was a significant, non dose-dependent relationship ( $\mathrm{p}<0.05$; student $\mathrm{t}$-test) when compared with negative control (distilled water). The aqueous extract showed seemingly dominant activity in the late phase of the test. But when the mean doses were tested multivariably with ANOVA, it displayed a statistically significant relationship $(\mathrm{p}<0.05)$ between $400 \mathrm{mg} / \mathrm{kg}$ dose $(\mathrm{p}=0.018)$ and $800 \mathrm{mg} / \mathrm{kg}$ dose $(\mathrm{p}=0.025)$ of the extracts of Bidens pilosa ((test of between-subjects effects). Further multiple test using Dunnett $\mathrm{t} 2$-paired tests revealed there was no significant difference $(\mathrm{p}=1.00$ and $>0.05)$ in both centrally and peripherally mediated analgesic activities between the aqueous and ethanolic extracts.

\subsection{Results of Tests of Bidens pilosa Extracts on Thermally Induced Pain in Rats (Tail-Flick Response Time)}

In Table 3, there was a general, irregular and non significant $(\mathrm{p}<0.05$; student $\mathrm{t}$-test), non dose dependent pattern of withdrawal of tail from the $55^{\circ} \mathrm{C}$ hot water by rats at both 30 and 60 minutes after administration of the aqueous and ethanolic extracts of Bidens pilosa when the test rats were compared with negative control (distilled water) and their own values at zero (0) minute. Two positive controls were used for the tail-flick test; the acetylsalicylic acid at $100 \mathrm{mg} / \mathrm{kg}$ and morphine at $2 \mathrm{~mL} / \mathrm{kg}$ of body weight. The rats administered with the positive controls showed prolonged time before withdrawal of the tail from the hot

Table 2. Effect of Bidens pilosa leaf extracts on formalin chemically induced pain in rats.

\begin{tabular}{|c|c|c|c|c|c|c|c|c|c|}
\hline & \multirow{3}{*}{ Dose (mg/kg) } & \multirow{3}{*}{$\begin{array}{c}\text { Distilled water } \\
(10 \mathrm{~mL} / \mathrm{kg})\end{array}$} & \multicolumn{7}{|c|}{ Treatments } \\
\hline & & & ASA & & BPA & & & $\mathrm{BPE}$ & \\
\hline & & & 100 & 200 & 400 & 800 & 200 & 400 & 800 \\
\hline \multirow{2}{*}{$\begin{array}{l}\text { Early } \\
\text { phase }\end{array}$} & Mean scores \pm SEM & $2.52 \pm 0.23$ & $1.96 \pm 0.29^{\star}$ & $1.56 \pm 0.50^{*}$ & $1.60 \pm 0.34^{*}$ & $1.08 \pm 0.42^{\star}$ & $1.60 \pm 0.42^{*}$ & $1.16 \pm 0.44^{*}$ & $1.44 \pm 0.50^{*}$ \\
\hline & Inhibition of pain (\%) & - & 22.2 & 38.1 & 36.5 & 57.2 & 36.5 & 54.0 & 42.9 \\
\hline \multirow{2}{*}{$\begin{array}{l}\text { Late } \\
\text { phase }\end{array}$} & Mean scores \pm SEM & $2.51 \pm 0.18$ & $2.09 \pm 0.19^{*}$ & $1.87 \pm 0.34^{*}$ & $1.29 \pm 0.41^{\star}$ & $1.67 \pm 0.48^{*}$ & $2.09 \pm 0.29$ & $1.80 \pm 0.46^{*}$ & $1.90 \pm 0.38^{*}$ \\
\hline & Inhibition of pain (\%) & - & 16.7 & 25.5 & 48.6 & 33.5 & 16.7 & 28.3 & 24.3 \\
\hline
\end{tabular}

$\mathrm{n}=5$, Data were mean $\pm \mathrm{SEM},{ }^{*}=$ test groups varied significantly $(\mathrm{p}<0.05)$ from normal saline group using student $\mathrm{t}$-test, ASA $=$ Acetylsalicylic Acid, Bidens pilosa leaf Aqueous Extract (BPA), Bidens pilosa leaf Ethanolic Extract (BPE). 
Table 3. Effect of aqueous and ethanolic extracts of Bidens pilosa leaf on thermally induced pain in rats.

\begin{tabular}{|c|c|c|c|c|c|c|c|c|c|c|}
\hline \multicolumn{11}{|c|}{ Treatments and Dose $(\mathrm{mg} / \mathrm{kg})$} \\
\hline & & \multirow{2}{*}{$\begin{array}{c}\text { Distilled } \\
\text { water } \\
(10 \mathrm{~mL} / \mathrm{kg})\end{array}$} & \multirow{2}{*}{ ASA (100) } & \multirow{2}{*}{$\begin{array}{l}\text { Morphine } \\
(2 \mathrm{~mL} / \mathrm{kg})\end{array}$} & \multicolumn{3}{|c|}{ BPA } & \multicolumn{3}{|c|}{ BPE } \\
\hline & & & & & 200 & 400 & 800 & 200 & 400 & 800 \\
\hline \multirow{5}{*}{$\begin{array}{c}\text { MTRT } \\
(\mathrm{sec}) \pm \\
\text { SEM }\end{array}$} & Zero $\min \left(\mathrm{T}_{0}\right)$ & $3.44 \pm 0.24$ & $3.22 \pm 0.26^{*}$ & $3.34 \pm 0.12$ & $3.34 \pm 0.26^{*}$ & $3.32 \pm 0.26^{*}$ & $3.50 \pm 0.14$ & $1.39 \pm 0.14$ & $1.38 \pm 0.13$ & $1.40 \pm 0.13$ \\
\hline & 30 mins $\left(T_{1}\right)$ & $3.66 \pm 0.28$ & $3.84 \pm 0.34$ & $4.80 \pm 0.03^{*}$ & $3.38 \pm 0.28$ & $3.68 \pm 0.11$ & $3.64 \pm 0.30$ & $1.47 \pm 0.09$ & $1.40 \pm 0.18$ & $1.64 \pm 0.13$ \\
\hline & 60 mins $\left(\mathrm{T}_{2}\right)$ & $3.56 \pm 0.28$ & $3.86 \pm 0.29$ & $4.70 \pm 0.07^{\star}$ & $3.50 \pm 0.20$ & $3.52 \pm 0.11$ & $3.54 \pm 0.14$ & $1.40 \pm 0.08$ & $1.49 \pm 0.16$ & $1.41 \pm 0.16$ \\
\hline & $\mathrm{T}_{1}-\mathrm{T}_{0}$ & $0.22 \pm 0.37$ & $0.62 \pm 0.14$ & $1.46 \pm 0.11^{*}$ & $0.04 \pm 0.13$ & $0.36 \pm 0.23$ & $0.14 \pm 0.31$ & $0.08 \pm 0.14$ & $0.02 \pm 0.25$ & $0.24 \pm 0.12$ \\
\hline & $\mathrm{T}_{2}-\mathrm{T}_{0}$ & $0.12 \pm 0.37$ & $0.64 \pm 0.31$ & $1.36 \pm 0.16^{*}$ & $0.16 \pm 0.14$ & $0.20 \pm 0.21$ & $0.04 \pm 0.16$ & $0.01 \pm 0.13$ & $0.01 \pm 0.14$ & $0.01 \pm 0.14$ \\
\hline \multirow{4}{*}{ PI (\%) } & $\mathrm{T}_{1}(0 \mathrm{~min}=$ reference $)$ & - & 19.3 & 30.4 & 1.2 & 1.1 & 2.9 & 5.8 & 1.5 & 17.1 \\
\hline & $\mathrm{T}_{2}(0 \mathrm{~min}=$ reference $)$ & - & 19.9 & 28.9 & 4.8 & 6.0 & 1.2 & 0.7 & 8.0 & 0.7 \\
\hline & $\mathrm{T}_{1}(\mathrm{DW}=$ reference $)$ & - & 4.9 & 23.6 & - & 0.6 & - & - & - & 7.9 \\
\hline & $\mathrm{T}_{2}(\mathrm{DW})=$ reference & - & 8.4 & 24.3 & - & - & - & - & - & - \\
\hline
\end{tabular}

$\mathrm{n}=5$; Data were mean $\pm \mathrm{SEM} ;{ }^{*}=$ test groups varied significantly $(\mathrm{p}<0.05)$ from normal saline group using student $\mathrm{t}$-test; MTRT $(\mathrm{sec})=$ Mean Tail Response Time (seconds); PI = Pain Inhibition; DW = Distilled Water; ASA = Acetylsalicylic acid; BPA = Bidens pilosa leaf Aqueous extract; $\mathrm{BPE}=$ Bidens pilosa leaf Ethanolic extract. 
eral wellbeing and quality of life of the patient [15] [53] [54]. A study of 137 AIDS patients on use of traditional herbal medicine in Kabarole District of Western Uganda by Langlois-Klassen et al. [18] revealed that patients use herbal medicine for relief of pain and fever. Nevertheless, $70 \%$ of these patients who use the herbal remedies for various purposes do not tell their doctors about these herbs [55]. Equally, very few researchers and people are privy to the limited data about these patients on prevalence, patterns of use, indications, effectiveness and safety of the herbs they use. However, some of these herbal remedies appear to be effective in relief of symptoms e.g. IGM-1 and no antiviral and immune effects [56]. In addition, most of the herbal remedies used by different patients have not been identified, qualified, quantified and analysed for their active and inactive constituents [18]. Results from larger studies are important to support this evidence as expressed by Liu [56] and therefore, Bidens pilosa was investigated in this study to substantiate the traditional healers' claims as the traditional basis for the use of Bidens pilosa leaf aqueous and ethanolic extracts in the treatment of pain involvement of oral lesions of HIV/AIDS patients.

The acetic acid induced writhing pain test method was used to study the anti-nociceptive effects of the aqueous and ethanolic extracts of Bidens pilosa in mice (Table 1). It is through these test methods that the anti-nociceptive mechanisms of the test samples are often identified and determined. In the acetic acid induced (chemical pain) test, $10 \mathrm{~mL} / \mathrm{kg}$ of $0.7 \%$ of acetic acid was administered intraperitoneally to induce writhe-like pain in the mice [43] [44]. The acetic acid produces writhes through stimulation of the release of various peripheral endogenous pain mediators which in turn animate the nociceptors [57] [58] thereby increasing the level of prostaglandins (PGE2 and PGF2 $\alpha$ ) and lipooxygenase in the fluid in the peritoneum [59]. The $\mathrm{C}$ fibres are responsible for mediating the resulting slow and poorly localized pain [60]. Data resulting from the current study showed significant dose-dependent $(\mathrm{p}<0.05$, student $\mathrm{t}$-test) inhibition of acetic acid induced pain by acetylsalicylic acid, aqueous and ethanolic extracts of Bidens pilosa, when compared with the negative control (normal saline). Statistical test with ANOVA revealed more analgesic activity with 200 and $400 \mathrm{mg} / \mathrm{kg}$ doses than $800 \mathrm{mg} / \mathrm{kg}$ dose. However, with Dunnett $\mathrm{t}$ 2-paired tests, the analgesic activities of aqueous and ethanolic extracts of Bidens pilosa were confirmed to be statistically similar. This analgesic activity presumably could be attributable to the presence of flavonoids as revealed by our previous study [61]. This result therefore holds the opinion that the realized anti-nociceptive activity of the extracts could be derived from the previously stated two broad groups of phytochemical components in the Bidens pilosa extracts such as flavonoids and polyacetylene groups [35] [62] [63] [64]. The basis of this reported analgesic activity originates from the ability of these constituents in $B i$ dens pilosa to reduce pain due to inflammation and this report was corroborated by Yoshida [65] on the competence of these constituents to relax muscle and relieve pain. Our results and the subsequent confirmation from previous works highly indicate the reasons and scientific basis for a region wide use of Bidens 
pilosa by traditional healers and locals in the treatment of oral lesions of HIV/AIDS in South-Western Uganda. This conceivably suggests that the reported analgesic and anti-inflammatory effects of both aqueous and ethanolic extracts of Bidens pilosa may attest to the extracts' pain and inflammation reducing capability and hence can offer relief to HIV/AIDS patients with pain and inflammation due to oral lesions.

Formalin test was used to study the scientific basis for the traditional use of aqueous and ethanolic extracts of Bidens pilosa against inflammation and pain in the oral lesions of HIV/AIDS patients (Table 2). Formalin test is usually used to investigate the effects of drugs on chemically induced analgesia. Formalin is an agent with the potential to induce oedema which in turn induces inflammation by releasing several inflammatory mediators including prostaglandins, histamine, serotonin, bradykinin [46] [60]. There are two phases in formalin test; one, is neurogenic pain in the first phase ( 0 - 10 minutes) in which case the nociceptors are directly stimulated, without any activity on these nociceptors by anti-inflammatory agents and two, is inflammatory pain in the second phase (15 - 60 minutes) which is directly related to peripheral inflammation and centrally mediated changes resulting from chemical mediators from damaged cells. Centrally acting agents have equal inhibition on both phases. Peripherally acting agents have inhibition only on the second phase. This test, in essence, assesses the response to an enduring nociceptive stimulus comparable to clinical pain and is recommended as a tool in basic pain research for studying the mechanisms of analgesic agents due to its association to tissue injury [46]. The formalin test with aqueous and ethanolic extract of Bidens pilosa leaf demonstrated a statistically significant, non dose dependent pain inhibition in both neurogenic and inflammatory phases when compared with the negative control (distilled water) [ $\mathrm{p} \leq 0.05$ for aqueous extract $(200 \mathrm{mg} / \mathrm{kg}$ early phase $\mathrm{p}=0.016$, late phase $\mathrm{p}=$ $0.01482 ; 400 \mathrm{mg} / \mathrm{kg}$ early $\mathrm{p}=0.0704$, late phase $\mathrm{p}=0.0002 ; 800 \mathrm{mg} / \mathrm{kg}$ early $\mathrm{p}=$ 0.0090 , late phase $\mathrm{p}=0.0002)]$ and for ethanolic extract $(400 \mathrm{mg} / \mathrm{kg}$ early $\mathrm{p}=$ 0.0125 , late phase $\mathrm{p}=0.0194 ; 800 \mathrm{mg} / \mathrm{kg}$ early $\mathrm{p}=0.0058$, late phase $\mathrm{p}=$ 0.0047)], student t-test). Further multiple testing with Dunnett $t$ 2-paired tests revealed no significant difference in centrally and peripherally mediated analgesic activities shown by both the aqueous and ethanolic extracts. Our observation was supported by display of anti-inflammatory properties of Bidens pilosa reported by Geissberger and Sequin [66]; its anti-inflammatory, muscle relaxant and pain-relieving effects by Yoshida [65]; and immunomodulatory, antioxidant and cellular protective properties by Chiang [67]; treatment of headache in Zulu land by inhibiting cyclooxygenase, an activity associated with the flavonoid components reported by Jager [63]. These results therefore suggest that the anti-nociceptive activity of the extracts of Bidens pilosa is as a result of the phytochemical components of the extracts which include flavonoids and polyacetylene groups [61] or polyynes, flavonoids, phenylpropanoids, fatty acids, and phenolics [20] such as alkaloids, tannins, terpenoids, saponins, phenolic compounds and steroids; thereby proving its efficacy in the traditional medicine system in 
management of pain involvement of oral lesions of HIV/AIDS patients in South Western Uganda.

The tail immersion test is a standard model for selective investigation of centrally but not peripherally mediated nociception and analgesia utilising thermal painful stimuli [47]. This method measures a response to a brief, noxious stimulus seemingly emanating from reflexes of the spinal cord modulated by supraspinal inhibitory mechanisms, indicating morphine-like effect implicating the activity of selective centrally acting analgesics [68] [69]. Pain stimulus is initiated through the A $\delta$ fibres and inhibited centrally or through interaction with the widely distributed opioid receptors at peripheral sites [57]. Our findings on tail-flick test with Bidens pilosa extracts in Table 3 showed the presence of a central analgesic activity. I did et al. [70] stated that hot plate tail flick technique has bias for centrally acting agents but not sufficiently sensitive to distinguish between opiates and non-opiates with central activity. Conversely, in the work of Pizziketti et al. [71], they revealed that the cold tail flick test has sufficiently demonstrated differentiation of opiates from non-opiates with central activity. However, Domer [72] in his study emphasised that the type of analgesic activities exhibited by Bidens pilosa indicates morphine-like activity and that corroborates the results of our present study. This formed the basis for the use of morphine as one of the positive controls in this study. In another study, Fields in his work [73] explained that this type of analgesic activity shown by Bidens pilosa can be referred to as NSAIDs-like occurring through inhibition of cyclooxygenase in peripheral tissues thereby interfering with the mechanism of transduction in primary afferent nociceptors. In another situation, this was the reason for using aspirin as another positive control for NSAID-like phytochemicals in Bidens pilosa. The contributory factor for these activities can be associated with presence of phytochemicals in the plants such as tannins, flavonoids, phlobatannins, terpenoids and cardiac glycosides [61]. In this present study, hot aqueous extract of Bidens pilosa was found to contain saponins, flavonoids, terpenoids and phenolic compounds while its cold ethanolic extract contained alkaloids, tannins, steroids, terpenoids and cardiac glycosides (Unpublished data). Any of these phytochemical components or their combinations could be the effective phytochemicals responsible for the observed analgesic effects of aqueous and ethanolic extracts of Bidens pilosa. Other preceding studies demonstrated the anti-inflammatory properties of Bidens pilosa by Geissberger and Sequin [66]; anti-inflammatory and muscle relaxant and pain-relieving effects [65]. All the stated results of tail flick test go further to accentuate the capability of Bidens pilosa extract to control both centrally and peripherally mediated pain, confirming the scientific basis of its traditional use in treatment of painful and inflammatory conditions and oral lesions of HIV/AIDS patients in South Western Uganda. The implication is that Bidens pilosa extracts have found use in treatment of pain and inflammation involvement of oral lesions of HIV/AIDS patients. 


\section{Conclusion and Recommendations}

In conclusion, Bidens pilosa possesses significant analgesic effects based on acetic acid, formalin and tail-flick induced pain tests in rats and can be used in the treatment of pain involvement of oral lesions of HIV/AIDS patients to justify its use for this purpose by traditional healers and other local users of the herb. We hereby recommend that further studies be conducted on the anticonvulsant property and mechanisms of action of the analgesic activities of Bidens pilosa with identified drug entities responsible for the activities to conclude the reason for the analgesic effects of Bidens pilosa.

\section{Acknowledgements}

We thank Mr. Ronald Kizza for his technical assistance in the School of Pharmacy Laboratories of Kampala International University and School of Pharmacy of Kampala International University Western Campus Ishaka Bushenyi Uganda for providing the laboratory space and some materials for the tests.

\section{Ethical Approval}

Ethical approval was sought and given by Uganda National Council for Science and Technology (UNCST) and Mbarara University of Science and Technology Institution's Research and Ethics Committees. These clearances enabled us to use the plants and the animals for this research.

\section{Competing Interests}

There is no conflict of interest among the authors.

\section{Authors' Contributions}

The authors worked together in conducting the tests involved as follows: JOCE initiated the study. Authors JOCE, EA, AAA, JCE and FB collected the data. Authors JOCE, MN, SOO, EA, COO and FB designed the study, wrote and corrected the protocol. Authors JKT and JOCE wrote the protocol and the first draft of manuscript, searched for literature, analyzed the data, read through the data and made corrections. Authors MN, SOO, EA and FB managed the experimental processes, read through and made corrections to the manuscript draft. Authors COO, JCE and AAA read through and made corrections to the manuscript draft. All authors read and approved the manuscript for publication.

\section{Consent}

Written consent was sought and secured from the Kampala International University School of Pharmacy Research Laboratories, Ishaka, Bushenyi where the animals were kept.

\section{Consent to Publish}

The authors consented to publishing of this article. 


\section{References}

[1] Merskey, H., Albe Fessard, D.G. and Bonica, J.J. (1979) Pain Terms: A List with Definitions and Notes on Usage. Pain, 6, 249-252.

[2] Melzack, R. and Wall, P. (1982) The Challenge of Pain. Penguin, London.

[3] Loeser, J.D. and Melzack, R. (1999) Pain: An Overview. Lancet, 353, 1607. https://doi.org/10.1016/S0140-6736(99)01311-2

[4] Agbelusi, G.A. and Wright, A.A. (2005) Oral Lesions as Indicators of HIV Infection among Routine Dental Patients in Lagos, Nigeria. Oral Disinfection, 1, 370-373. https://doi.org/10.1111/j.1601-0825.2005.01132.x

[5] Onunu, A.N. and Obuekwe, N. (2002) HIV-Related Oral Diseases in Benin City, Nigeria. West African Journal of Medicine, 21, 9-11.

[6] Arendorf, T.M., Bredekamp, B. and Cloete, C. (1997) Intergroup Comparisons of Oral Lesions in HIV Positive South Africans. Oral Disinfection, 3, 54-57. https://doi.org/10.1111/j.1601-0825.1997.tb00375.x

[7] Arendorf, T.M., Bredekamp, B., Cloete, C.A. and Sauer, G. (1998) Oral Manifestations of HIV Infection in 600 South African Patients. Journal of Oral Pathology and Medicine, 27, 176-179. https://doi.org/10.1111/j.1600-0714.1998.tb01936.x

[8] Jonsson, N., Zimmerman, M., Chidzonga, M.M. and Jonsson, K. (1998) Oral Manifestations in 100 Zimbabwean HIV/AIDS Patients Referred to a Specialist Centre. Central African Journal of Medicine, 44, 31-34.

[9] Agwu, E., Ihongbe, J.C., Tirwomwe, J.F., Pazos, V., Tirwomwe, M. and Casadesus, L. (2008b) Appraisal of Oral Lesions Status of HIV/AIDS Patients in South Western Uganda. Brazilian Journal of Oral Science, 7, 1591-1595.

[10] Tirwomwe, J.F., Rwenyonyi, C.M., Muwazi, L.M., Besigye, B. and Mboli, F. (2007) Oral Manifestations of HIV/AIDS in Clients Attending TASO Clinics in Uganda. Clinical Oral Investigation, 11, 3. https://doi.org/10.1007/s00784-007-0118-z

[11] Muzyka, B.C. and Glick, M. (1994) Major Oral Ulcerations in HIV Disease. Oral Surgery, Oral Medicine, Oral Pathology, 77, 116-120. https://doi.org/10.1016/0030-4220(94)90271-2

[12] Hewitt, D.J., McDougald, M. and Portenoy, R.K. (1997) Pain Syndromes and Aetiologies in Ambulatory AIDS Patients. Pain, 70, 117-123.

https://doi.org/10.1016/S0304-3959(96)03281-2

[13] Kayombo, E.J., Uiso, F.C., Mbwambo, Z.H., Mahunnah, R.L., Moshi, M.J. and Mgonda, Y.H. (2007) Experience of Initiating Collaboration of TH in Managing HIV and AIDS in Tanzania. Journal of Ethnobiology and Ethnomedicine, 3, 6. https://doi.org/10.1186/1746-4269-3-6

[14] British National Formulary (BNF) (2009) Side Effects of Non-Steroidal Anti-Inflammatory Drugs. 57, 552-561.

[15] Dhalla, S., Chan, K.J., Montaner, J.S. and Hogg, R.S. (2006) Complementary and Alternative Medicine Use in British Columbia-A Survey of HIV Positive People on Antiretroviral Therapy. Complementary Therapeutics and Clinical Practice, 12, 242-248. https://doi.org/10.1016/j.ctcp.2006.05.002

[16] London, A.S., Foote-Ardah, C.E., Fleishman, J.A. and Shapiro, M. (2003) Use of Alternative Therapists among People in Care for HIV in the United States. American Journal of Public Health, 93, 980-987. https://doi.org/10.2105/AJPH.93.6.980

[17] Wiwanitkit, V. (2003) The Use of CAM by HIV-Positive Patients in Thailand. Complement. Therapeutics and Medicine, 11, 39-41. https://doi.org/10.1016/S0965-2299(02)00108-5 
[18] Langlois-Klassen, D., Kipp, W., Jhangri, G.S. and Rubaale, T. (2007) Use of Traditional Herbal Medicine by AIDS Patients in Kabarole District, Western Uganda. American Journal of Tropical Medicine and Hygiene, 77, 757-763.

[19] Grubben, G.J.H. and Denton, O.A. (2004) Plant Resources of Tropical Africa 2. Vegetables. PROTA Foundation, Wageningen; Backhuys, Leiden; CTA, Wageningen.

[20] Bartolome, A.P., Villaseñor, I.M. and Yang, W. (2013) Bidens pilosa L. (Asteraceae): Botanical Properties, Traditional Uses, Phytochemistry, and Pharmacology. Evidence-Based Complementary and Alternative Medicine, 2013, Article ID: 340215. https://doi.org/10.1155/2013/340215

[21] Rokaya, M.B., Munzbergova, Z., Timsina, B. and Bhattarai, K.R. (2012) Rheum australe D. Don: A Review of Its Botany, Ethnobotany, Phytochemistry and Pharmacology. Journal of Ethnopharmacology, 141, 761-774.

https://doi.org/10.1016/j.jep.2012.03.048

[22] Young, P.H., Hsu, Y.J. and Yang, W.C. (2010) Bidens pilosa L. and Its Medicinal Use. In: Awaad, A.S., Singh, V.K. and Govil, J.N., Eds., Recent Progress in Medicinal Plants Drug Plant II, Standium Press, Houston, Texas, USA.

[23] Karis, P.O. and Ryding, O. (1994) Asteraceae: Cladistics and Classification. Timber Press, Portland, Oregon, USA, 559-569.

[24] Pozharitskaya, O.N., Shikov, A.N., Makarova, M.N., et al. (2010) Anti-Inflammatory Activity of a HPLC-Fingerprinted Aqueous Infusion of Aerial Part of Bidens tripartita L. Phytomedicine, 17, 463-468. https://doi.org/10.1016/j.phymed.2009.08.001

[25] Oliveira, F.Q., Andrade-Neto, V., Krettli, A.U. and Brandão, M.G.L. (2004) New Evidences of Antimalarial Activity of Bidens pilosa Roots Extract Correlated with Polyacetylene and Flavonoids. Journal of Ethnopharmacology, 93, 39-42. https://doi.org/10.1016/j.jep.2004.03.026

[26] Long, C., Sauleau, P., David, B., et al. (2003) Bioactive flavonoids of Tanacetum parthenium Revisited. Phytochemistry, 64, 567-569. https://doi.org/10.1016/S0031-9422(03)00208-5

[27] United States Department of Agriculture, Plants Database (2013) Natural Resources Conservation Service. http://www.nrcs.usda.gov/wps/portal/nrcs/site/national/home

[28] Chien, S.C., Young, P.H., Hsu, Y.J., et al. (2009) Anti-Diabetic Properties of Three Common Bidens pilosa Variants in Taiwan. Phytochemistry, 70, 1246-1254. https://doi.org/10.1016/j.phytochem.2009.07.011

[29] Alcaraz, M.J. and Jimenez, M.J. (1988) Flavonoids as Anti-Inflammatory Agents. Fitoterapia, 59, 25-38.

[30] FAO (1997) Agriculture Food and Nutrition for Africa-A Resource Book for Teachers of Agriculture. Publishing Management Group, FAO Information Division, Rome, Italy.

[31] Mvere, B. (2004) Bidens pilosa L. Record from Protabase. In: Grubben, G.J.H. and Denton, O.A., Eds., PROTA 2: Vegetables/Légumes., CD-Rom, PROTA, Wageningen, Netherlands.

[32] Rojas, J.J., Ochoa, V.J., Ocampo, S.A. and Muno, J.F. (2006) Screening for Antimicrobial Activity of Ten Medicinal Plants Used in Colombian Folkloric Medicine: A Possible Alternative in the Treatment of Non-Nosocomial Infections. BMC Complementary and Alternative Medicine, 6, 2. https://doi.org/10.1186/1472-6882-6-2

[33] Watt, J.M. and Breyer-Brandwijk, M.G. (1962) The Medicinal and Poisonous Plants of Southern and Eastern Africa. 2nd Edition, E. and S. Livingstone Ltd., Edinburgh. 
[34] Dimo, T., Rakotonirina, S.V., Tan, P.V., Azay, J., Dongo, E. and Cros, G. (2002) Leaf Methanol Extract of Bidens pilosa Prevents and Attenuates the Hypertension Induced by High-Fructose Diet in Wistar Rats. Journal of Ethnopharmacology, 83, 183-191. https://doi.org/10.1016/S0378-8741(02)00162-9

[35] Brandão, M.G., Krettli, A.U., Soares, L.S., Nery, C.G. and Marinuzzi, H.C. (1997) Antimalarial Activity of Extracts and Fractions from Bidens pilosa and Other Bidens Species (Asteraceae) Correlated with the Presence of Acetylene and Flavonoid Compound. European Journal Pharmacology, 57, 131-138.

https://doi.org/10.1016/S0378-8741(97)00060-3

[36] Chiang, Y.M., Chuang, D.Y., Wang, S.Y., Kuo, Y.H., Tsai, P.W. and Shyur, L.F. (2004) Metabolite Profiling and Chemopreventive Bioactivity of Plant Extracts from Bidens pilosa. Journal of Ethnopharmacology, 95, 409-419.

[37] Olajide, O. (2010) Epistemological Issues in the Making of an African Medicine: Sutherlandia (Lessertia frutescens). African Sociology Review, 14, 74-88.

[38] Cos, P., Vlietinck, A.J., Berghe, D.V. and Maes, L. (2006) Anti-Infective Potential of Natural Products: How to Develop a Stronger in Vitro "Proof-of-Concept". Journal of Ethnopharmacology, 106, 290-302. https://doi.org/10.1016/j.jep.2006.04.003

[39] NIH (1996) Guide for the Care and Use of Laboratory Animals. National Academic Press.

[40] Zimmerman, M. (1983) Ethical Guidelines for Investigations of Experimental Pain in Conscious Animals. Pain, 16,109-110. https://doi.org/10.1016/0304-3959(83)90201-4

[41] Koster, R., Anderson, M. and De Beer, E.J. (1959) Acetic Acid for Analgesic Screening. Federation Proceedings, 18, 412-417.

[42] Collier, H.O., Dinneen, L.C., Johnson, C.A. and Schneider, C. (1968) The Abdominal Constriction Response and Its Suppression by Analgesic Drugs in the Mouse. British Journal of Pharmacology, 32, 295-310.

[43] Fukui, M., Nakagawa, T., Minami, M., Satoh, M. and Kaneko, S. (2006) Inhibitory Role of Supraspinal $\mathrm{P} 2 \mathrm{X}_{3} / \mathrm{P}_{2} \mathrm{X}_{2 / 3}$ Subtypes on Nociception in Rats. Molecular Pain, 2, 19-24. https://doi.org/10.1186/1744-8069-2-19

[44] Loro, J.F., del Rio, I. and Perez-Santana, L. (1999) Preliminary Studies of Analgesic and Anti-Inflammatory Properties of Opuntia dillenii Aqueous Extract. Journal of Ethnopharmacology, 67, 213-218. https://doi.org/10.1016/S0378-8741(99)00027-6

[45] Dubuission, D. and Dennis, S.G. (1977) The Formalin Test: A Quantitative Study of the Analgesic Effect of Morphine, Meperidine, and Brain Stem Simulation in Rats and Cats. Pain, 4, 161-174. https://doi.org/10.1016/0304-3959(77)90130-0

[46] Tjolsen, A., Berge, O.G., Hunskaar, S., Rosland, J.H. and Hole, K. (1992) The Formalin Induced Test: An Evaluation of the Method. Pain, 51, 5-14. https://doi.org/10.1016/0304-3959(92)90003-T

[47] D’Armour, F.E. and Smith, D.L. (1941) A Method for Determining Loss of Pain Sensation. Journal of Pharmacology and Experimental Therapeutics, 72, 74-79.

[48] Janssen, P.A.J., Niemegeers, C.J.E. and Dony, J.G.H. (1963) The Inhibitory Effect of Fentanyl and Other Morphine-Like Analgesic on the Warm Water Induced Tail Withdrawal Reflex in Rats. Arzneimittel-Forschung, 6, 502-507.

[49] Asongalem, E.A., Foyet, H.S., Ekobo, S., Folefoc, G.N., Dimo, T. and Kamchouing, P. (2004) Anti-Inflammatory, Lack of Central Analgesia and Anti-Pyretic Properties of Acanthus montanus (Ness) T Anderson. Journal of Ethnopharmacology, 95, 63-68. https://doi.org/10.1016/j.jep.2004.06.014 
[50] Asongalem, E.A., Foyet, H.S., Ngogang, J., Folefoc, G.N., Dimo, T. and Kamchouing, P. (2004) Analgesic and Anti-Inflammatory Activities of Ergeron floribundus. Journal of Ethnopharmacology, 91, 301-308. https://doi.org/10.1016/j.jep.2004.01.010

[51] Rabanal, R.M., Bonkanka, C.X., Hernandez-Perez, M. and Sanchez-Mateo, C.C. (2005) Analgesic and Topical Anti-Inflammatory Activity of Hypericum canriense L. and Hypericum glandulosum Ait. Journal of Ethnopharmacology, 96, 591-596. https://doi.org/10.1016/j.jep.2004.10.013

[52] Sanchez-Mateo, C.C., Bonkanka, C.X., Hernandez-Perez, and Rabanal, R.M. (2006) Evaluation of Analgesic and Topical Anti-Inflammatory Effects of Hypericum reflexum L. Fil. Journal of Ethnopharmacology, 107, 1-6. https://doi.org/10.1016/j.jep.2006.01.032

[53] Furler, M.D., Einarson, T.R., Walmsley, S., Millson, M. and Bendayan, R. (2003) Use of Complementary and Alternative Medicine by HIV-Infected Outpatients in Ontario, Canada. AIDS Patient Care and STDs, 17, 155-168. https://doi.org/10.1089/108729103321619764

[54] Kirksey, K.M., Goodroad, B.K., Kemppainen, J.K., Holzemer, W.L., Bunch, E.H., Corless, I.B., Eller, L.S., Nicholas, P.H., Nokes, K. and Bain, C. (2002) Complementary Therapy Use in Persons with HIV/AIDS. Journal of Holistic Nursing, 20, 264-278. https://doi.org/10.1177/089801010202000306

[55] Dwyer, J.T., Salvato-Schille, A.M., Coulston, A., Casey, V.A., Cooper, W.C. and Selles, W.D. (1995) The Use of Unconventional Remedies among HIV-Positive Men Living in California. Journal of the Association of Nurses in AIDS Care, 6, 17-28. https://doi.org/10.1016/S1055-3290(05)80026-3

[56] Liu, J. (2007) The Use of Herbal Medicines in Early Drug Development for the Treatment of HIV Infections and AIDS. Expert Opinions on Investigations and Drugs, 16, 1355-1364. https://doi.org/10.1517/13543784.16.9.1355

[57] Raj, P.P. (1996) Pain Mechanisms. In: Raj, P.P., Ed., Pain Medicine, a Comprehensive Review, Mosby-Year Book, St. Louis, USA, 12-24.

[58] Anoka, A.N., Adzu, B., Amon, G.A., Byarugaba, D. and Díaz-Llera, S. (2008) The Analgesic and Antiplasmodial Activities and Toxicology of Vernonia amygdalina. Journal of Medicine and Food, 11, 574-580. https://doi.org/10.1089/jmf.2007.0511

[59] Du, J., Yu, Y., Ke, Y., Wang, C., Zhu, L. and Qian, Z.M. (2007) Ligustilide Attenuates Pain Behaviour Induced by Acetic Acid or Formalin. Journal of Ethnopharmacology, 112, 211-214. https://doi.org/10.1016/j.jep.2007.02.007

[60] Bennett, P.N. and Brown, M.J. (2003) Nervous System: Pain and Analgesia; Clinical Pharmacology. 9th Edition, Churchill Livingstone Press, London, 319-323.

[61] Ezeonwumelu, J.O.C., Julius, A.K., Muhoho, C.N., Ajayi, A.M., Oyewale, A.A., Tanayen, J.K., Balogun, S.O., Ibrahim, A., Adzu, B., Adiukwu, C.P., Oloro, J., Kiplagat, D.M., Goji, A.D.T., Okoruwa, A.G., Onchweri, A.N. and Reddy, P.M.K. (2011) Biochemical and Histological Studies of Aqueous Extract of Bidens pilosa Leaves from Ugandan Rift Valley in Rats. British Journal of Pharmacology and Toxicology, 2, 302-309.

[62] Sundararajan, P., Dey, A., Gnana Dhas, A.S.A. and Natarajan, S. (2006) Studies of Anticancer and Antipyretic Activity of Biden pilosa Whole Plant. African Health Science, 6, 27-30.

[63] Jager, A., Hutchings, A. and van Staden, J. (1996) Screening of Zulu Medicinal Plants for Prostaglandin Synthesis Inhibitors. Journal of Ethnopharmacology, 52, 95-100. https://doi.org/10.1016/0378-8741(96)01395-5 
[64] Hou, D., Guo, Q., Li, Y., Li, L., Wang, Q., Yi, Q. and Tang, M. (1989) Effects of Anticancer No. 8 Drugs on the Experimental Tumours in Mice. Journal of China Pharmaceutical University, 20, 348-350.

[65] Yoshida, N., Kanekura, T., Higashi, Y. and Kanzaki, T. (2006) Bidens pilosa Suppresses Interleukin-1beta-Induced Cyclooxygenase-2 Expression through the Inhibition of Mitogen Activated Protein Kinases Phosphorylation in Normal Human Dermal Fibroblasts. Journal of Dermatology, 33, 676-683.

[66] Geissberger, P. and Sequin, U. (1991) Constituents of Bidens pilosa L. Do the Components Found so far Explain the Use of This Plant in Traditional Medicine? Acta Tropics, 48, 251-261. https://doi.org/10.1016/0001-706X(91)90013-A

[67] Chiang, Y.M., Chang, C.L., Chang, S.L., Yang, W.C. and Shyur, L.F. (2006) Cytopiloyne, a Novel Polyacetylenic Glucoside from Bidens pilosa, Functions as a T Helper Cell Modulator. Journal of Ethnopharmacology, 19, 176-183.

[68] Adzu, B. and Haruna, A.K. (2007) Studies on the Use of Zizyphus sphina-christi against Pain in Rats and Mice. African Journal of Biotechnology, 6, 1317-1324.

[69] Ramabadran, K., Bansinath, M., Turndorf, H. and Puig, M.M. (1989) Tail Immersion Test for the Evaluation of a Nociceptive Reaction in Mice: Methodological Consideration. Journal of Pharmacology and Methods, 21, 21-31. https://doi.org/10.1016/0160-5402(89)90019-3

[70] Idid, S.Z., Saad, L.B., Yaacob, H. and Shahimi, M.M. (1998) Evaluation of Analgesia Induced by Mitragynine, Morphine and Paracetamol on Mice. ASEAN Review of Biodiversity and Environmental Conservation (ARBEC), 4, 1-7.

[71] Pizziketti, R.J., Pressman, N.S., Geller, E.B. and Adler, M.W. (1985) Rat Cold Water Tail-Flick: A Novel Analgesic Test that Distinguishes Opioid Agonist from Mixed Agonist-Antagonist. European Journal of Pharmacology, 119, 23-29. https://doi.org/10.1016/0014-2999(85)90317-6

[72] Domer, F. (1990) Characterization of the Analgesic Activity of Ketorolac in Mice. European Journal of Pharmacology, 177, 127-135. https://doi.org/10.1016/0014-2999(90)90262-5

[73] Fields, H.L. (1987) Analgesic Drugs. In: Day, W., Ed., Pain, MacGraw-Hill, USA, 272. 


\section{Abbreviations}

OIs: Opportunistic Infections.

ANOVA: Analysis Of Variance.

ART: Antiretroviral Therapy.

AFC: Animal Facility Centre.

NIH: National Institute of Health.

i.p: Intraperitoneally.

p.o: per oral.

SEM: Standard Error of the Mean.

BPA: Bidens pilosa Leaf Aqueous Extract.

BPE: Bidens pilosa Leaf Ethanolic Extract.

MTRT: Mean Tail Response Time.

PI: Pain Inhibition.

DW $=$ Distilled Water.

sec: seconds.

NSAIDs: Non Steroidal Anti-inflammatory Drugs. 